BeAta ZIĘBA*

\title{
OPIS PRZEDMIOTU ZAMÓWIENIA PUBLICZNEGo POPRZEZ ODNIESIENIE SIĘ DO ZNAKÓW TOWAROWYCH, PATENTÓW, NORM, SPECYFIKACJI
}

Można zaryzykować stwierdzenie, że przygotowanie dobrego opisu przedmiotu zamówienia jest jednym $\mathrm{z}$ najtrudniejszych, a jednocześnie podstawowym działaniem zamawiającego, który chce wszcząć postępowanie o udzielenie zamówienia publicznego.

Dokonywany opis konkretnego i potrzebnego przedmiotu zamówienia wpływa na przebieg postępowania o udzielenie zamówienia publicznego oraz stanowi o istotnych postanowieniach późniejszej umowy. Należy przy tym zauważyć, iż określenie przedmiotu zamówienia jest zarazem obowiązkiem jak i uprawnieniem zamawiającego, co jeszcze bardziej podkreśla jego doniosłość. Określenie przedmiotu zamówienia w sposób obiektywny, z zachowaniem zasad ustawowych, nie jest jednoznaczne z koniecznością zdolności realizacji zamówienia przez wszystkie podmioty działające na rynku w danej branży.

W niniejszym artykule zaprezentowano w sposób ogólny analizę przepisów prawa dotyczących opisu przedmiotu zamówienia poprzez odniesienie do norm lub specyfikacji pod kątem praktycznym, zasygnalizowano wielość problemów pojawiających się w stosowaniu prawa w praktyce, możliwości rozwiązywania tych problemów, uwrażliwiono odbiorcę na konieczność zapoznania się z orzecznictwem wspólnotowym i polskim w celu prawidłowej interpretacji przepisów. Artykuł ma stanowić zachętę do dokładniejszego przypatrzenia się regulacjom dotyczącym

* Mgr, Katolicki Uniwersytet Lubelski Jana Pawła II; e-mail: zieba@kul.pl. 
opisu przedmiotu zamówienia poprzez odniesienie się do norm, znaków towarowych, patentów czy specyfikacji technicznych.

$\mathrm{Na}$ początek zaznaczyć należy iż, gospodarzem całego procesu udzielania zamówienia publicznego jest zamawiający i to on kreuje jego ramy oraz między innymi dokonuje opisu przedmiotu zamówienia. Z tego powodu szczególnie ważny jest fakt, że zamawiający zobowiązany jest działać $\mathrm{w}$ granicach i zgodnie $\mathrm{z}$ przepisami prawa, $\mathrm{w}$ tym prawa zamówień publicznych, zaś $\mathrm{w}$ innym wypadku podlegać będzie odpowiednim sankcjom. Jego działania są weryfikowane zarówno przez wykonawców, jak i instytucje i urzędy kontrolujące oraz przez Krajową Izbę Odwoławczą i sądy. Zamawiającemu nie wolno sporządzać opisu, który mógłby utrudniać uczciwą konkurencję ${ }^{1}$. Do stwierdzenia nieprawidłowości w opisie przedmiotu zamówienia, a tym samym sprzeczności z prawem, wystarczy jedynie zaistnienie możliwości utrudniania uczciwej konkurencji poprzez zastosowanie określonych zwrotów opisujących sposób realizacji zamówienia². Na zamawiającym ciąży szczególna odpowiedzialność, gdyż powinien on tak szczegółowo i dokładnie określić swoje wymagania dotyczące opisu przedmiotu zamówienia, aby każdy wykonawca był w stanie zidentyfikować, czego zamawiający oczekuje. Obowiązkiem zamawiającego jest podjęcie wszelkich możliwych środków w celu wyeliminowania elementu niepewności wykonawców co do przedmiotu zamówienia, poprzez maksymalnie jednoznaczne i wyczerpujące określenie przedmiotu zamówienia ${ }^{3}$. Zamawiający jest zobowiązany zachować niezbędną równowagę i proporcję między interesem polegającym na uzyskaniu rękojmi należytego wykonania zamówienia a interesem potencjalnych wykonawców, których nie można, poprzez wprowadzenie nadmiernych wymagań co do opisu przedmiotu zamówienia, z góry eliminować z udziału w postępowaniu, czy też utrudniać im udział w postępowaniu o zamówienie publiczne ${ }^{4}$.

${ }^{1}$ J. Andała-Sępkowska, Ograniczenia w opisie przedmiotu zamówienia i warunków realizacji przyszłej umowy, LEX nr 277599.

${ }^{2}$ Wyrok Krajowej Izby Odwoławczej (dalej KIO) z dnia 27 marca 2015 r., KIO 496/15; orzecznictwo Krajowej Izby Odwoławczej dostępne na: https://www.uzp.gov.pl/kio/ orzecznictwo/wyroki [dostęp: 1.10.2018 r.].

${ }^{3}$ Wyrok KIO z dnia 6 lipca 2015 r., KIO 1332/15.

${ }^{4}$ Wyrok KIO z dnia 24 kwietnia 2017 r., KIO 664/17. 
Zgodnie z normą prawna, przedmiotu zamówienia nie można opisywać przez wskazanie znaków towarowych ${ }^{5}$, patentów ${ }^{6}$ lub pochodzenia $^{7}$, źródła lub szczególnego procesu ${ }^{8}$, który charakteryzuje produkty lub usługi dostarczane przez konkretnego wykonawcę, jeżeli mogłoby to doprowadzić do uprzywilejowania lub wyeliminowania niektórych wykonawców lub produktów, chyba że jest to uzasadnione specyfiką przedmiotu zamówienia i zamawiający nie może opisać przedmiotu zamówienia za pomocą dostatecznie dokładnych określeń, a wskazaniu takiemu towarzyszą wyrazy „lub równoważny”. . W związku z tym, opisanie przedmiotu zamówienia przez wskazanie znaków towarowych jest możliwe tylko w sytuacji, gdy kumulatywnie zostaną spełnione następujące przesłanki: ze względu na specyfikę przedmiotu zamówienia zamawiający nie może opisać przedmiotu zamówienia za pomocą dostatecznie dokładnych określeń oraz wskazaniu takiemu towarzyszy sformułowanie „lub równoważny”. Niemożność opisania przedmiotu zamówienia musi być obiektywna, a specyfika przedmiotu zamówienia uzasadniona, wynikająca z jego cech technicznych, jakościowych lub funkcjonalnych ${ }^{10}$.

${ }^{5}$ Znak towarowy to marka, termin lub symbol wykorzystywany w celu odróżnienia konkretnego produktu od produktów konkurencyjnych. Znakiem towarowym może być w szczególności wyraz, rysunek, ornament, kompozycja kolorystyczna, forma przestrzenna, w tym forma towaru lub opakowania, a także melodia lub inny sygnał dźwiękowy. Znakami towarowymi są także znaki usługowe, art. 120 ustawy z dnia 30 czerwca $2000 \mathrm{r}$. Prawo własności przemysłowej, Dz. U. z 2017 r. poz. 776, tekst jednolity.

${ }^{6}$ Patenty są udzielane - bez względu na dziedzinę techniki - na wynalazki, które są nowe, posiadają poziom wynalazczy i nadają się do przemysłowego stosowania, art. 24 ustawy z dnia 30 czerwca 2000 r. Prawo własności przemysłowej.

7 Pojęcie pochodzenia dotyczy kraju lub regionu pochodzenia, jest więc oznaczeniem geograficznym, o którym mowa w art. 174 ust. 1 ustawy z dnia 30 czerwca 2000 r. Prawo własności przemysłowej. Oznaczeniami geograficznymi w rozumieniu ustawy są oznaczenia słowne odnoszące się bezpośrednio lub pośrednio do nazwy miejsca, miejscowości, regionu lub kraju (teren), które identyfikują towar jako pochodzący z tego terenu, jeżeli określona jakość, dobra opinia lub inne cechy towaru są przypisywane przede wszystkim pochodzeniu geograficznemu tego towaru, za: J.E. Nowicki, A. Bazan, Prawo zamówień publicznych. Komentarz, Warszawa 2015, s. 439.

8 Źródło lub szczególny proces charakteryzujący produkt lub usługę konkretnego wykonawcy oznacza niemal każdy dostępny element potwierdzający, że w opisie przedmiotu zamówienia wskazano produkt danego producenta, za: G. Mazurek, S. Zaręba, Ustawa o zmianie ustawy Prawo zamówień publicznych. Komentarz, Wrocław 2016, s. 206.

9 Art. 29 ust. 3 ustawy Prawo zamówień publicznych z dnia 29 stycznia 2004 r., Dz. U. 2017 r. poz. 1579 z późn. zm. (dalej PZP).

${ }^{10}$ J.E. Nowicki, A. Bazan, Prawo zamówień publicznych. Komentarz, Warszawa 2015, s. 434. 
Norma ta ma charakter przepisu lex specialis, co oznacza, iż w każdym przypadku, gdy zamawiający ma możliwość opisania przedmiotu zamówienia bez konieczności posłużenia się nazwami własnymi, to powinien tak postąpićn ${ }^{11}$. W tym znaczeniu opis przedmiotu zamówienia sporządzony z wykorzystaniem znaków towarowych, patentów lub pochodzenia, źródła lub procesu, zawsze uzupełniony o obligatoryjne oświadczenie zamawiającego o dopuszczeniu składania ofert równoważnych, nie zawęża dopuszczalnej konkurencji do ofert zawierających jedynie wskazane przedmioty lub technologie. Stanowi wyłącznie wzorzec jakościowy przedmiotu zamówienia, który w normalnych warunkach winien być przekazany oferentom jako zestaw obiektywnych cech jakościowych i technicznych. Jest zatem szczególną postacią obowiązku opisywania przedmiotu zamówienia stosowaną ze względu na specyfikę przedmiotu zamówienia i możliwości zamawiającego, który nie może sprecyzować przedmiotu zamówienia za pomocą typowego instrumentarium ${ }^{12}$. Jednocześnie podkreślić należy, iż dopuszczenie przez zamawiającego rozwiązań równoważnych nie może być jedynie pozorne, lecz musi dawać wszystkim wykonawcom realną możliwość zaoferowania produktu równoważnego ${ }^{13}$.

Zamawiający powinien samodzielnie opisać przedmiot zamówienia, a dopiero w sytuacji, gdy nie jest w stanie w sposób dostatecznie precyzyjny i zrozumiały przedstawić charakterystyki przedmiotu zamówienia, ani w trybie samodzielnego opisu, ani też poprzez odwołanie się do norm lub wspólnych specyfikacji, może odnieść się do konkretnej mar$\mathrm{ki}$, patentu, produkcji itp., zawsze jednak uzupełniając opis słowami: „lub równoważny"14. Powołany przepis wyraźnie wskazuje na wyjątkowość takiego sposobu sporządzania specyfikacji technicznej - zamawia-

${ }^{11}$ Przykłady naruszeń ustawy Pzp wykrywanych w toku kontroli przeprowadzonej przez Prezesa UZP w zakresie opisu przedmiotu zamówienia, „Informator Urzędu Zamówień Publicznych" 2011, nr 2, s. 9-10.

${ }^{12}$ M. Stachowiak, Komentarz do art. 29 ustawy Prawo zamówień publicznych, [w:] W. Dzierżanowki, J. Jerzykowski, M. Stachowiak, Prawo zamówień publicznych. Komentarz, Warszawa 2018, LEX nr 545201.

${ }^{13}$ Wyrok Wojewódzkiego Sądu Administracyjnego w Łodzi z dnia 22 marca 2017 r., IIISA/Łd 831/16, http://www.orzeczenia-nsa.pl/wyrok/iii-sa-ld-831-16/srodki_ unijne/1c1a20d.html [dostęp: 30.08.2018 r.].

${ }_{14}$ Zob. wyrok Sądu Okręgowego w Zielonej Górze z dnia 15 października 2007 r., V Gaz 90/07, [w:] K. Kumala, M. Pieklak, Czy można rozpisać przetarg na program lekowy, którego jeszcze nie ma, https://portal.dzp.pl/files/shares/Art/Czy_mozna_rozpisac_przetarg_na_program_lekowy.pdf [dostęp: 30.08.2018 r.]. 
jący w sposób obiektywny nie może być zdolny do sporządzenia właściwego opisu przedmiotu zamówienia bez odniesienia do przykładu $\mathrm{w}$ postaci marki, patentu czy znaku handlowego ${ }^{15}$. Jeśli nie zaistnieje taka wyjątkowa sytuacja, a zamawiający dokona takiego odniesienia w specyfikacji, nawet przy użyciu słów „lub równoważny”, może się narazić na zarzut naruszenia prawa unijnego i zasady uczciwej konkurencji. Samo dopuszczenie rozwiązań równoważnych nie jest bowiem usprawiedliwieniem dla odwołania się do konkretnego znaku w sytuacji, gdy opis przedmiotu zamówienia jest możliwy za pomocą podania cech technicznych i jakościowych lub wymagań funkcjonalnych.

Zakaz odnoszenia się $\mathrm{w}$ opisie przedmiotu zamówienia do konkretnych znaków towarowych czy patentów stanowi implementację dyrektywy ${ }^{16}$, która stanowczo stwierdza, że specyfikacje istotnych warunków zamówienia nie mogą zawierać odniesienia do konkretnej marki, źródła, znaku handlowego, patentu, typu, pochodzenia lub produkcji, które mogłyby prowadzić do uprzywilejowania lub wyeliminowania niektórych wykonawców albo produktów.

Ustawodawca zakazuje zamawiającemu używania $\mathrm{w}$ opisie przedmiotu zamówienia określeń wskazujących na konkretne produkty wiadomych producentów, nazwy materiałów i urządzeń czy sposób produkcji identyfikujący konkretnego wykonawcę. Użyte przez ustawodawcę pojęcie znaku towarowego należy utożsamiać $\mathrm{z}$ marka, terminem lub symbolem wykorzystywanym w celu odróżnienia konkretnego produktu od produktów konkurencyjnych ${ }^{17}$.

${ }^{15}$ Postanowienie KIO z dnia 12 października 2012 r., KIO 2145/12.

16 Art. 42 ust. 4 Dyrektywy 2014/24/UE Parlamentu Europejskiego i Rady z dnia 26 lutego 2014 r. w sprawie zamówień publicznych, uchylająca dyrektywę 2004/18/WE, Dz. Urz. UE L 94 z dnia 28.03.2014, s. 65 z późn. zm. (zwana dyrektywą klasyczną).

17 Przykład naruszenia $\mathrm{w}$ ten sposób zasady uczciwej konkurencji można znaleźć w wyroku z dnia 24 stycznia 1995 r. w sprawie C-359/93 Komisja WE v. Holandia. TSUE orzekł, że żądanie przez zamawiającego zastosowania systemu operacyjnego "UNIX" $\mathrm{w}$ kontraktach na dostawę systemu informacyjnego narusza art. 34 TFUE. Specyfikacja techniczna tego rodzaju eliminowała od udziału w przetargu wszystkich tych dostawców, którzy nie posługiwali się systemem „UNIX”, ale innymi podobnego lub tego samego rodzaju. Ograniczenie to było sprzeczne z prawem unijnym, mimo że dotyczyło zarówno oferentów holenderskich (przetarg był organizowany w Holandii), jak i pochodzących z innych państw członkowskich, za: https://www.uzp.gov.pl/_data/assets/pdf_ file/0026/28286/Orzeczenie2079_94.pdf [dostęp: 30.08.2018 r.]. 
$\mathrm{W}$ jednej $\mathrm{z}$ analiz ${ }^{18}$ zwraca się uwagę, że wskazywanie konkretnych nazw producentów lub produktów to nadal jeden $\mathrm{z}$ głównych mankamentów analizowanych przetargów ${ }^{19}$.

Przy opisywaniu przedmiotu zamówienia za pomocą znaków towarowych czy patentów, gdy zaistnieje taka konieczność, pamiętać należy, iż nie wystarczy samo posłużenie się sformułowaniem „lub równoważny". W takim przypadku opis przedmiotu zamówienia powinien zawierać precyzyjnie określone wymagania zamawiającego w odniesieniu do dopuszczanego przez niego zakresu równoważności oferty. Zamawiający powinien opisać rozwiązanie równoważne przez podanie zakresu lub zakresów równoważności dostawy, usługi lub roboty budowlanej, wyrażonych wielkościa, w szczególności parametrów technicznych, jakościowych i funkcjonalnych $^{20}$. Opis kryteriów równoważności musi mieć charakter katalogu zamkniętego ${ }^{21}$. Należy pamiętać, że przedmiot równoważny to produkt, który nie jest tożsamy z produktem referencyjnym, ale posiada pewne istotne dla zamawiającego, zbliżone do produktu referencyjnego cechy i parametry nie gorszej jakości, które powinny zostać określone w SIWZ. Wykonawca może wówczas wykazać równoważność wszelkimi dostępnymi dokumentami i wyjaśnieniami ${ }^{22}$.

Na gruncie tych rozwiązań warto zauważyć, że w doktrynie pojawił się pogląd, który dopuszcza możliwość użycia przy opisie przedmiotu zamówienia znaków towarowych, patentów lub pochodzenia nie tylko w sytuacji określonej w normie prawnej ${ }^{23}$, ale także wtedy, gdy opis bez tych oznaczeń byłby niezmiernie trudny i irracjonalny ${ }^{24}$. Obowiązek wykazania jednak tej „niezmiernej trudności” i „,irracjonalności” obciąża

18 A. Michałek-Budzicz, R. Michalski, M. Woźniak, Analiza rynku zamówień publicznych na narzędzia informatyczne w okresie od 1 stycznia do 30 czerwca 2013 r., Poznań 2013.

${ }_{19}$ G. Bliźniuk, Opis przedmiotu zamówienia, „Zamówienia Publiczne DORADCA" 2014, nr 3, s. 19.

${ }^{20}$ Zob. wyrok KIO z dnia 7 kwietnia 2008 r., KIO 254/08; wyrok KIO z dnia 9 sierpnia 2012 r., KIO 1615/12; wyrok KIO z dnia 19 marca 2013 r., KIO 516/13, a także wyrok KIO z dnia 20 grudnia 2013 r., KIO 2844/13. s. 436.

${ }^{21}$ J.E. Nowicki, A. Bazan, Prawo zamówień publicznych. Komentarz, Warszawa 2015,

${ }^{22}$ N. Gazecka, K. Różowicz, Zamówienia publiczne na dostawy i usługi IT. Wybrane zagadnienia praktyczne, Warszawa 2016, LEX nr 278004.

${ }^{23}$ Art. 29 ust. 3 PZP.

${ }^{24}$ T. Czajkowski (red.), Prawo zamówień publicznych. Komentarz, Warszawa 2007, s. 148. 
zamawiającego, który powinien przytoczyć stosowne okoliczności natury faktycznej ${ }^{25}$.

Znak towarowy często ma wpływ na pozycję rynkową przedsiębiorcy i traktowany jest jako składnik majątku przedsiębiorstwa ${ }^{26}$. Zazwyczaj jest to nazwa (albo jej skrót) przedsiębiorstwa wytwarzającego lub sprzedającego dany produkt. Najistotniejsza funkcja znaku towarowego polega na zagwarantowaniu konsumentowi lub użytkownikowi produktu autentyczności pochodzenia oznaczonego towaru lub oznaczonej usługi, przez umożliwienie mu odróżnienia tego towaru lub tej usługi od towarów lub usług o innym pochodzeniu ${ }^{27}$. Charakter znaku oparty jest o elementy wyróżniające, które w świadomości uczestników obrotu gospodarczego wskazują w sposób niebudzący wątpliwości, że towar w dany sposób oznaczony pochodzi od konkretnego przedsiębiorstwa ${ }^{28}$.

Ograniczeniem uczciwej konkurencji będzie także opis przedmiotu zamówienia na podstawie katalogu producenta, podział na pakiety lub części, tak, że wszystkie produkty w danym pakiecie lub częściach może dostarczyć tylko jeden wykonawca lub celowe łączenie w opisie przedmiotu zamówienia kilku dóbr, których uzyskanie jest możliwe oddzielnie. Naruszeniem zasady uczciwej konkurencji oraz zasady proporcjonalności będzie również dokonywanie opisu przedmiotu zamówienia przez wskazanie rygorystycznych wymagań, nieuzasadnionych potrzebami zamawiającego ${ }^{29}$.

Zamawiający jest zobowiązany dokonać opisu przedmiotu zamówienia: przez określenie wymagań dotyczących wydajności lub funkcjonalności, w tym wymagań środowiskowych, pod warunkiem, że podane parametry są dostatecznie precyzyjne, aby umożliwić wykonawcom ustalenie przedmiotu zamówienia; przez odniesienie się

25 P. Banasik, Specyfikacja istotnych warunków zamówienia, Wrocław 2011, s. 38.

${ }^{26} \mathrm{~W}$ rozumieniu art. 551 ustawy z dnia 23 kwietnia 1964 r. - Kodeks Cywilny, Dz. U. z 2014 r. poz. 121, tekst jednolity (dalej KC).

${ }^{27}$ Zob. wyrok TSUE z dnia 29 września 1998 r. w sprawie C-39/97 Canon Kabushiki Kaisha przeciwko Metro-Goldwyn-Mayer Inc., Zb. Orz. T.S i S.1998, s. I-5507; wyrok TSUE z dnia 4 października 2001 r. w sprawie C-517/99 Merz i Krell GmbH, http://curia.europa.eu/juris/ liste.jsf?language=en\&num=C-517/99 [dostęp: 30.08 .2018 r.].

${ }_{28}$ Zob. wyrok Naczelnego Sądu Administracyjnego z dnia 22 marca 2002 r., II SA 3847/01, „Monitor Prawniczy” 2002, nr 10, s. 436.

${ }^{29}$ D. Ziembiński, Zasada proporcjonalności, „ZAMAWIAJĄCY. Zamówienia publiczne w praktyce" 2017, nr 22, s. 20. 
w kolejności preferencji do: Polskich Norm $^{30}$ przenoszących normy europejskie, norm innych państw członkowskich Europejskiego Obszaru Gospodarczego ${ }^{31}$ przenoszących normy europejskie, europejskich ocen technicznych, wspólnych specyfikacji technicznych, norm międzynarodowych, specyfikacji technicznych lub innych systemów referencji technicznych; przez odniesienie do kategorii wymagań dotyczących wydajności lub funkcjonalności ${ }^{32}$.

W przypadku braku wymienionych wyżej norm przenoszących normy europejskie, zamawiający ma obowiązek uwzględnić w kolejności: Polskie Normy, polskie aprobaty techniczne, polskie specyfikacje techniczne, krajowe deklaracje zgodności itd. ${ }^{33} \mathrm{~W}$ ten sposób ustawodawca wskazał zamawiającym i wykonawcom preferowaną kolejność norm ${ }^{34}$.

Wskazany katalog metod, którymi może się posłużyć zamawiający, znacznie się rozszerzył po nowelizacji ustawy Prawo zamówień publicznych $^{35}$, co stanowi implementację dyrektywy $\mathrm{UE}^{36}$. Jeśli zamawiający nie odnoszą się do norm lub wspólnych specyfikacji, powinni stosować dokładne i zrozumiałe w danej branży określenia definiujące przedmiot zamówienia. Dokładny opis przedmiotu zamówienia jest również niezbędny dla prawidłowego oszacowania wartości przedmiotu zamówienia. Sporządzanie specyfikacji poprzez odniesienie do norm jakości nie oznacza, że zamawiający powinien przenieść do opisu całą treść takiej normy ${ }^{37}$. Jest on natomiast obowiązany do dokonania opisu przedmiotu zamówienia publicznego z poszanowaniem treści takiej normy lub kilku norm, przy zachowaniu uprawnienia do dokonywania pewnych zmian lub określe-

${ }^{30}$ Art. 5 ustawy z dnia 12 września 2002 r. o normalizacji (Dz. U. z 2002 r. Nr 169, poz. 1386 z późn. zm.) określa, że Polska Norma jest norma krajową przyjętą w drodze konsensusu i zatwierdzoną przez krajową jednostkę normalizacyjną powszechnie dostępną, oznaczoną na zasadzie wyłączności symbolem PN.

${ }^{31}$ W skrócie: EOG.

32 Zob. art. 30 ust. 1 ustawy PZP.

${ }^{33}$ Zob. art. 30 ust. 3 ustawy PZP.

${ }^{34}$ Zob. G. Mazurek, S. Zaręba, Ustawa o zmianie ustawy Prawo zamówień publicznych. Komentarz, Wrocław 2016, s. 216.

35 Nowelizacja nastąpiła na podstawie ustawy z dnia 22 czerwca 2016 r. o zmianie ustawy - Prawo zamówień publicznych oraz niektórych innych ustaw, Dz. U. z 2016 r. poz. 1020.

${ }^{36}$ Art. 42 ust. 3 Dyrektywy 2014/24/UE Parlamentu Europejskiego i Rady z dnia 26 lutego 2014 r. w sprawie zamówień publicznych, uchylająca dyrektywę 2004/18/WE, Dz. Urz. UE L94 z 28.03.2014, s. 65 z późn. zm.

37 J. Piróg, Prawo zamówień publicznych. Komentarz, Warszawa 2010, s. 158-159. 
nia wymogów nieregulowanych przez daną normę. Zamawiający nie jest ograniczony obowiązkiem bezpośredniego powoływania się na konkretne normy i może podnieść swoje wymagania w stosunku do wymogów uregulowanych przez daną normę czy specyfikację techniczną a także może ustanowić wymagania wykraczające poza kwestie uregulowane w danym dokumencie, jeśli tylko nie będzie naruszało zasady uczciwej konkurencji. Wymaganie zamawiającego przewyższające postanowienia PolskichNormniestanowiojego sprzecznościlubniezgodnościztreściąnorm ${ }^{38}$. Zamawiający opisuje przedmiot zamówienia z „zachowaniem” Polskich Norm przenoszących normy europejskie ${ }^{39}$, co wskazuje jedynie na pomocniczy charakter norm w określeniu minimalnych lub maksymalnych wymagań dotyczących przedmiotu zamówienia ${ }^{40}$. Normy podają minimalne wartości progowe, a zamawiający ma prawo oczekiwać dostarczenia produktu o parametrach wyższych niż minimalne ${ }^{41}$. Treści powyższego przepisu nie należy interpretować jako nakazu dokonywania opisu przedmiotu zamówienia ściśle za pomocą tych norm. Posługiwanie się przez zamawiających normami powinno uwzględniać cele regulacji wspólnotowych, a przygotowywana specyfikacja powinna umożliwić wykonawcom jednakowy dostęp i nie może powodować tworzenia nieuzasadnionych przeszkód w otwarciu zamówień publicznych na konkurencję. Normy europejskie zawarte $\mathrm{w}$ dyrektywach, zbliżające podstawowe wymogi dotyczące harmonizowanych produktów, mają na celu wyeliminowanie barier w handlu pomiędzy państwami członkowskimi UE i tym samym, zrównanie szans przedsiębiorców. Celem norm europejskich jest zatem między innymi usprawnienie procesu legalnego wprowadzania do obrotu określonych produktów na terytorium innego państwa członkowskiego UE. Biorąc pod uwagę okoliczność, że przyjmowane normy europejskie opierają się na standardach uznanych za wystarczające dla zapobieżenia nieuzasadnionej odmowie wprowadzenia produktu na rynek $\mathrm{w}$ innym państwie członkowskim UE, zamawiający stawiając wymogi odnośnie nabywanego dobra „powyżej” standardów unijnych powinien szczególnie

${ }^{38}$ Wyrok KIO z dnia 2 kwietnia 2008 r., KIO 236/08.

39 Art. 30 ust. 1 ustawy PZP.

${ }^{40}$ J.E. Nowicki, A. Bazan, Prawo zamówień publicznych. Komentarz, Warszawa 2015, s. 449 .

${ }^{41}$ Zob. wyrok KIO z dnia 1 kwietnia 2011 r., KIO 590/11, za: J.E. Nowicki, A. Bazan, Prawo zamówien publicznych, s. 449. 
należycie uzasadnić, $\mathrm{w}$ razie sporu, przyczynę takiego opisu przedmiotu zamówienia.

Konstruowanie opisu przedmiotu zamówienia za pomocą norm, aprobat i specyfikacji technicznych musi uwzględnić okoliczności związane z udzielaniem danego zamówienia na wspólnym rynku ${ }^{42}$. Zamawiający nie może posługiwać się wyłącznie normami krajowymi, ponieważ działania takie prowadziłyby do bezpośredniej dyskryminacji wykonawców pochodzących z innych państw członkowskich $\mathrm{UE}^{43}$.

Zamawiający może również opisać przedmiot zamówienia za pomocą cech technicznych i jakościowych, bez odnoszenia się do norm - prawo unijne rozróżnia sytuację, w której opis w kategoriach charakterystyki odbywa się $\mathrm{w}$ odniesieniu do norm i specyfikacji, oraz przypadki opisu bez zachowania norm, ponieważ przepis prawa ${ }^{44}$ przewiduje samodzielne określenie przedmiotu zamówienia w kategoriach charakterystyki lub wymagań funkcjonalnych. "Samodzielność" nie dotyczy zatem tylko opisu za pomocą wymagań funkcjonalnych, ale również w kategoriach charakterystyki (cech technicznych i jakościowych).

Zamawiający nie może żądać od wykonawców, by oferowali produkty lub usługi, które uzyskały uprzednio certyfikat zgodności z konkretną normą, bez umożliwienia przedstawienia rozwiązań równoważnych ${ }^{45}$.

${ }^{42}$ G. Karwatowicz, M. Lamch-Rejowska, Zamówienia publiczne w projektach wspótfinansowanych ze środków unijnych, Wrocław 2011, s. 55.

${ }^{43}$ Wyrok TSUE z dnia 26 września 2000 r. C-225/98 w sprawie Komisja przeciw Republice Francuskiej, [w:] M. Lemke, D. Piasta, Urząd Zamówień Publicznych, Analiza orzecznictwa Europejskiego Trybunału Sprawiedliwości dotyczacego zamówień publicznych w okresie od 1999 do 2005 r., Warszawa 2006, s. 211.

44 Art. 23 ust. 3 pkt b) Dyrektywy 2004/18/WE.

45 Przykładowo w wyroku z dnia 22 września 1988 roku w sprawie C-45/87 Dundalk, TSUE stwierdził, że specyfikacja techniczna dotycząca rodzaju rur, które miały być użyte przy konstruowaniu sieci wodociągowej, dyskryminowała przedsiębiorców z innych państw członkowskich UE, albowiem zamawiający zażyczył sobie, by zastosowano określony typ rur, posiadający certyfikat zgodności ze standardami irlandzkimi, wydawany zgodnie z procedurami ustanowionymi przez irlandzki Instytut do spraw Badań Naukowych i Standaryzacji. W czasie przeprowadzania przetargu rury odpowiadające wymogom specyfikacji technicznej opracowanej przez zamawiającego produkowało tylko jedno irlandzkie przedsiębiorstwo. Pozostali oferenci byli natomiast pozbawieni prawa zaoferowania innych rur, chociażby o takim samym standardzie, ponieważ zamawiający nie umieścił w specyfikacji żadnego takiego zastrzeżenia. Trybunał uznał jednak, że cele, na które powołała się Irlandia, mogły być osiągnięte w mniej restrykcyjny sposób - wystarczyłoby umieszczenie w specyfikacji słów „lub inne ekwiwalentne z przedstawionymi standardami”, za: A. Sołtysińska, H. Talago-Sławoj, Europejskie prawo zamówień publicznych. Komentarz, Warszawa 2016, s. 410-411. 
TSUE orzekł, że takie postępowanie będzie stanowiło naruszenie nie tylko przepisów dyrektywy regulującej procedury udzielania zamówień publicznych, ale również zasady swobodnego przepływu towarów ${ }^{46}$.

Niestety, z punktu widzenia możliwości wprowadzenia rozwiązań innowacyjnych, opis techniczny przy wykorzystaniu norm i specyfikacji znacznie ogranicza nowatorskie rozwiązania, ponieważ zamawiający $\mathrm{z}$ góry $\mathrm{w}$ dużej mierze determinuje przedmiot umowy i metodę realizacji. Pojęcia użyte $w$ polskim prawodawstwie zostały zdefiniowane $w$ prawie unijnym ${ }^{47}$. Po pierwsze definicja „normy” jako specyfikacji technicznej zatwierdzonej przez uznaną instytucję normalizacyjną w celu powtarzalnego i stałego stosowania, której przestrzeganie nie jest obowiązkowe, i która należy do jednej z następujących kategorii: „norma międzynarodowa” - norma przyjęta przez międzynarodową organizację normalizacyjną oraz dostępna publicznie, „norma europejska" - norma przyjęta przez europejską organizację normalizacyjną oraz dostępna publicznie, „norma krajowa” - norma przyjęta przez krajową organizację normalizacyjną oraz dostępna publicznie. Po drugie ustawodawca wspólnotowy definiuje również „europejską aprobatę techniczną" jako pozytywną ocenę techniczną przydatności produktu do użycia w konkretnym celu, dokonana w oparciu o spełnienie podstawowych wymagań dla robót budowlanych, według charakterystyki własnej produktu oraz określonych warunków jego zastosowania i użytkowania. Europejskie aprobaty techniczne są wydawane przez organ zatwierdzający, wyznaczony do tego celu przez państwo członkowskie. Normy wspólnotowe zawierają również wyjaśnienie „wspólnej specyfikacji technicznej" jako specyfikacji technicznej określonej zgodnie z procedurą uznaną przez państwa członkowskie i opublikowanej w Dzienniku Urzędowym Unii Europejskiej ${ }^{48}$. Na marginesie należy zwrócić uwagę, że zamawiający nie jest instytucją powołaną do kontroli, czy dany produkt rzeczywiście spełnia wszystkie cechy opisane $\mathrm{w}$ normie stanowiącej podstawę do wydania certyfikatu w przypadku, gdy wykonawca dowodzi, że oferowane dobro uzyskało

46 Zasadę tę formułuje art. 34 Traktatu o Funkcjonowaniu UE (dalej TFUE), Dz. Urz. UE C115 z 9.05.2008.

47 Załącznik VII do Dyrektywy 2014/24/UE, Dz. Urz. UE L94 z 28.03.2014.

${ }^{48}$ J. Pawelec, Dyrektywa 2014/24/UE w sprawie zamówień publicznych. Komentarz, Warszawa 2015, s. 218-219. 
już takie poświadczenie jakości. TSUE stwierdzi1 ${ }^{49}$, że zamawiający, który zorganizował przetarg na dostawę wyrobów medycznych (nici chirurgicznych) spełniających wymagania $\mathrm{CE}$, nie może odrzucić ze względów dotyczących ochrony zdrowia publicznego oferty na takie wyroby kwestionując ich jakość i brak cech wymaganych przez wystawcę CE. Argumentując, że oferowane produkty opatrzone oznakowaniem CE mogą stanowić zagrożenie dla zdrowia publicznego, zamawiający jest zobowiązany powiadomić właściwy krajowy organ w celu wszczęcia takiej procedury ochronnej - dopiero taki kompetentny organ w porozumieniu z Komisją Europejską może podjąć stosowne środki prawie.

Przy opisie przedmiotu zamówienia zamawiający stosuje nazwy i kody określone we Wspólnym Słowniku Zamówień CPV ${ }^{50}$. Określa on jednolity system klasyfikacji mający zastosowanie do zamówień publicznych w celu ujednolicenia odniesień stosowanych przez instytucje i podmioty zamawiające do opisu przedmiotu zamówienia ${ }^{51}$.

Podsumowując, podkreślić ponownie należy iż opis przedmiotu zamówienia sporządzony przez zamawiającego ma istotne znaczenie na etapie przygotowania postępowania o udzielenie zamówienia publicznego, jest jedną z najważniejszych czynności związanych z przygotowaniem postępowania o udzielenie zamówienia, gdyż jest niezbędny dla ustalenia wartości zamówienia, a także powinien odpowiadać rzeczywistym potrzebom zamawiającego. $Z$ tego powodu zamawiający przygotowując postępowanie powinien dokonać opisu z zachowaniem należytej staranności, dokładnie i konkretnie formułując swoje wymagania, a w przypadku, gdy decyduje się na dokonanie opisu poprzez odniesienie się do znaków towarowych, patentów, norm i specyfikacji, powinien to zrobić umiejętnie, znając wszystkie zasady i granice odpowiedzialności.

Słowa kluczowe: Prawo zamówień publicznych, opis przedmiotu zamówienia, zamówienie publiczne, postępowanie o udzielenie zamówienia pub-

49 Wyrok z dnia 19 marca 2009 roku sprawie C-489/06, Komisja v. Grecja, Dz. Urz. UE C113/04 z 16.05.2009.

${ }^{50}$ Przyjęte rozporządzeniem Komisji (WE) nr 213/2008 z dnia 28 listopada 2007 r. zmieniającym rozporządzenie (WE) nr 2195/2002 Parlamentu Europejskiego i Rady w sprawie Wspólnego Słownika Zamówień (CPV) oraz dyrektywy 2004/17/WE i 2004/18/WE Parlamentu Europejskiego i Rady dotyczące procedur udzielania zamówień publicznych w zakresie zmiany CPV, Dz. Urz. UE L74 z 15.03.2008.

${ }^{51}$ G. Karwatowicz, M. Lamch-Rejowska, Zamówienia publiczne w projektach wspótfinansowanych ze środków unijnych, Wrocław 2011, s. 56. 
licznego, zamawiający, wykonawca, orzecznictwo, specyfikacja przedmiotu zamówienia, równoważność w opisie przedmiotu zamówienia, dyrektywa, normy polskie, normy europejskie

\section{Bibliografia}

\section{Źródła prawa}

\section{Akty prawa wspólnotowego i polskiego}

Traktat o Funkcjonowaniu UE, Dz. Urz. UE C115 z 9.05.2008.

Rozporządzenie Komisji (WE) nr 213/2008 z dnia 28 listopada 2007 r. zmieniające rozporządzenie (WE) nr 2195/2002 Parlamentu Europejskiego i Rady w sprawie Wspólnego Słownika Zamówień oraz dyrektywy nr 2004/17/ WE i 2004/18/WE Parlamentu Europejskiego i Rady dotyczące procedur udzielania zamówień publicznych w zakresie zmiany CPV, Dz. Urz. UE L74 z 15.03.2008.

Dyrektywa 2014/24/UE Parlamentu Europejskiego i Rady z dnia 26 lutego 2014 r. w sprawie zamówień publicznych, uchylająca dyrektywę 2004/18/ WE, Dz. Urz. UE L94 z 28.03.2014, s. 65-242 z późn. zm.; Załącznik VII do Dyrektywy 2014/24/UE, Dz. Urz. UE L94 z 28.03.2014.

Ustawa z dnia 23 kwietnia 1964 r. - Kodeks Cywilny, Dz. U. z 2014 r. poz. 121, tekst jednolity.

Ustawa z dnia 30 czerwca 2000 r. Prawo własności przemysłowej, Dz. U. z 2017 r. poz. 776, tekst jednolity.

Ustawa z dnia 12 września 2002 r. o normalizacji, Dz. U. z 2002 r. Nr 169, poz. 1386 z późn. zm.

Ustawa z dnia 29 stycznia 2004 r. - Prawo zamówień publicznych, Dz. U. z 2017 r. poz. 1579 z późn. zm.

Ustawa z dnia 22 czerwca 2016 r. o zmianie ustawy - Prawo zamówień publicznych oraz niektórych innych ustaw, Dz. U. z 2016 r. poz. 1020.

\section{Orzecznictwo wspólnotowe i polskie}

Wyrok TSUE z dnia 22 września 1988 r. w sprawie C-45/87 Dundalk, [w:] A. Sołtysińska, H. Talago-Sławoj, Europejskie prawo zamówień publicznych. Komentarz, Warszawa 2016, s. 410-411.

Wyrok TSUE z dnia 24 stycznia 1995 r. w sprawie C-359/93 Komisja WE v. Holandia, https://www.uzp.gov.pl/_data/assets/pdf_file/0026/28286/Orzeczenie2079_94.pdf [dostęp: 30.08.2018 r.].

Wyrok TSUUE z dnia 29 września 1998 r. w sprawie C-39/97 Canon Kabushiki Kaisha przeciwko Metro-Goldwyn-Mayer Inc., Zb. Orz. T.S i S.1998, s. I-5507. 
Wyrok TSUE z dnia 26 września 2000 r. w sprawie C-225/98 Komisja przeciw Republice Francuskiej, [w:] M. Lemke, D. Piasta, Urzad Zamówień Publicznych, Analiza orzecznictwa Europejskiego Trybunału Sprawiedliwości dotyczacego zamówień publicznych w okresie od 1999 do 2005 r., Warszawa 2006, s. 211.

Wyrok TSUE z dnia 4 października 2001 r. w sprawie C-517/99 Merz i Krell $\mathrm{GmbH}$, http://curia.europa.eu/juris/liste.jsf?language=en\&num=C-517/99 [dostęp: 30.08.2018 r.].

Wyrok z dnia 19 marca 2009 r. sprawie C-489/06 Komisja v. Grecja, Dz. Urz. UE C113/04 z 16.05.2009.

Wyrok Naczelnego Sądu Administracyjnego z dnia 22 marca 2002 r., II SA 3847/01, „Monitor Prawniczy” 2002, nr 10, s. 436.

Wyrok Sądu Okręgowego w Zielonej Górze z dnia 15 października 2007 r., V Gaz 90/07, [w:] K. Kumala, M. Pieklak, Czy można rozpisać przetarg na program lekowy, którego jeszcze nie ma, https://portal.dzp.pl/files/shares/Art/Czy_mozna_rozpisac_przetarg_na_program_lekowy.pdf [dostęp: 30.08.2018 r.].

Wyrok Wojewódzkiego Sądu Administracyjnego w Łodzi z dnia 22 marca 2017 r., IIISA/Łd 831/16, http://www.orzeczenia-nsa.pl/wyrok/iii-sa-ld-831-16/srodki_unijne/1c1a20d.html [dostęp: 30.08.2018 r.].

\section{Postanowienia i wyroki Krajowej Izby Odwoławczej}

Orzecznictwo Krajowej Izby Odwoławczej dostępne na: https://www.uzp. gov.pl/kio/orzecznictwo/wyroki [dostęp: 1.10.2018 r.]

Postanowienie KIO z dnia 12 października 2012 r., KIO 2145/12.

Wyrok KIO z dnia 2 kwietnia 2008 r., KIO 236/08.

Wyrok KIO z dnia 7 kwietnia 2008 r., KIO 254/08.

Wyrok KIO z dnia 1 kwietnia 2011 r., KIO 590/11.

Wyrok KIO z dnia 9 sierpnia 2012 r., KIO 1615/12.

Wyrok KIO z dnia 19 marca 2013 r., KIO 516/13.

Wyrok KIO z dnia 20 grudnia 2013 r., KIO 2844/13.

Wyrok KIO z dnia 27 marca 2015 r., KIO 496/15.

Wyrok KIO z dnia 6 lipca 2015 r., KIO 1332/15.

Wyrok KIO z dnia 24 kwietnia 2017 r., KIO 664/17.

\section{Literatura}

Andała-Sępkowska J., Ograniczenia w opisie przedmiotu zamówienia i warunków realizacji przyszłej umowy, LEX nr 277599.

Banasik P., Specyfikacja Istotnych Warunków Zamówienia, Wrocław 2011.

Bliźniuk G., Opis przedmiotu zamówienia, „Zamówienia Publiczne DORADCA" 2014, nr 3, s. 19. 
Czajkowski T. (red.), Prawo zamówień publicznych. Komentarz, Warszawa 2007.

Gazecka N., K. Różowicz, Zamówienia publiczne na dostawy i usługi IT. Wybrane zagadnienia praktyczne, Warszawa 2016, LEX nr 278004.

Karwatowicz G., M. Lamch-Rejowska, Zamówienia publiczne w projektach wspótfinansowanych ze środków unijnych, Wrocław 2011.

Mazurek G., S. Zaręba, Ustawa o zmianie ustawy Prawo zamówień publicznych. Komentarz, Wrocław 2016.

Michałek-Budzicz A., R. Michalski, M. Woźniak, Analiza rynku zamówień publicznych na narzędzia informatyczne w okresie od 1 stycznia do 30 czerwca 2013 r., Poznań 2013.

Nowicki J.E., A. Bazan, Prawo zamówień publicznych. Komentarz, Warszawa 2015.

Pawelec J., Dyrektywa 2014/24/UE w sprawie zamówień publicznych. Komentarz, Warszawa 2015.

Piróg J., Prawo zamówień publicznych. Komentarz, Warszawa 2010.

Stachowiak M., Komentarz do art. 29 ustawy Prawo zamówień publicznych, [w:] W. Dzierżanowski, J. Jerzykowski, M. Stachowiak, Prawo zamówień publicznych. Komentarz, Warszawa 2018, LEX nr 545201.

Ziembiński D., Zasada proporcjonalności, „ZAMAWIAJĄCY. Zamówienia publiczne w praktyce" 2017, nr 22, s. 20.

Przykłady naruszeń ustawy Pzp wykrywanych w toku kontroli przeprowadzonej przez Prezesa UZP w zakresie opisu przedmiotu zamówienia, "Informator Urzędu Zamówień Publicznych" 2011, nr 2, s. 9-10.

\section{DESCRIPTION OF THE OBJECT \\ IN THE PUBLIC PROCUREMENT BY REFERENCE TO TRADEMARKS, PATENTS, STANDARDS, SPECIFICATIONS}

\section{S u m m a r y}

This article presents an analysis of the legal regulations concerning the description of the subject-matter of the contract by reference to trade marks, patents, standards, specifications and the problems that may arise while applying those regulations in practice. The author states that the subject matter of the contract can not be described by the indication of the trade mark, patent or origin, source or particular process that characterizes the products or services provided by the particular contractor, if this leads to the privilege or elimination of certain contractors or products, justified by the specific nature of the object of the contract and the contracting authority can not describe the object of the contract with sufficiently precise terms, the indication is accompanied by the words "or equivalent”. The structuring of the description of the subject of the contract by means of standards, approvals and technical specifications must take into account circumstances related to the award of the relevant contract on the Polish and Community market. The emphasis is on the fact that if the contracting party has the ability to describe the subject of the 
contract without the need to use own names, then it should do so. If the contracting party chooses to do so by referring to trademarks, patents, standards and specifications, it should be done knowingly (with accurate precision) and with knowledge of the rules and limits of liability in this regard.

Key words: public procurement law, description of the object of contract, public procurement, public contract awarding procedure, contracting entity, economic operator, judicature, detailed description (specification) of the subject-matter of the contract, equivalence of the description of the object of contract, directive, polish standards, european standards

\section{ОПИСАНИЕ ПРЕДМЕТА ГОСУ ДАРСТВЕННОГО ЗАКАЗА КАСАТЕДЬНО ТОВАРНЫХ ЗНАКОВ, ПАТЕНТОВ, НОРМ, СПЕЦИФИКАЦИЙ}

\section{P e 3 г м e}

В данной статье представлен анадиз положений права, касающихся описания предмета заказа по товарным знакам, патентам, нормам, спецификациям, а также показаны проблемы, которые могут возникнуть во время применения данных положений в практике. Автор указывает, что предмета заказа нельзя описывать через указание товарных знаков, патентов или происхождения, источника или особенного процесса, который характеризует продукты или услуги, предоставленые конкретным исполнителем, если могло бы это привести к привилегии или исключении некоторых исполнителей или продуктов, разве что это обосновано спецификой предмета заказа и заказывающий не может описать предмета заказа с помощью достаточно подробных понятий, а такое указание подлежат выражению „или равновесный”. Конструирование описания предмета заказа с помощью норм, утверждений и технических спецификаций должено учитывать обстоятельства, связанные с предоставлением данного заказа на рынке, как подьском, так и общественном. Следует подчеркнуть факт, что если заказывающий имеет возможность описания предмета заказа без необходимости того, чтобы воспользоваться собственными названиями, тогда должен так поступить. Если же Заказывающий решается на выполнение описания касательно товарных знаков, патентов, норм и спецификаций, должен это сделать умело, зная принципы и границы ответственности в этой сфере.

Ключевые слова: Право государственных заказов, описание предмета заказа, государственный заказ, процес по предоставлению государственного заказа, заказывающий, исполнитель, вынесение решения, спецификация предмета заказа, эквивалентность в описании предмета заказа, директива, польские нормы, европейские нормы 